\title{
Freezing avoidance mechanisms in juveniles of giant rosette plants of the genus Espeletia
}

\author{
Sonia García-Varela, Fermín Rada * \\ Facultad de Ciencias, Instituto de Ciencias Ambientales y Ecológicas (ICAE), Universidad de Los Andes, Mérida, Venezuela
}

\begin{abstract}
Along soil-air gradients in tropical high mountains, plants growing at soil level tolerate frost while those growing well above ground, including all species in the genus Espeletia, use freezing avoidance mechanisms to survive low nighttime temperatures. The question that arises and the objective of this work were: What are the low temperature resistance mechanisms in giant rosettes when they are within the juvenile stages, i.e. closer to the ground? Juveniles of Espeletia spicata and Espeletia timotensis, dominant plants of the high Venezuelan Andes, were chosen for this study. To determine resistance mechanisms for these species, air and leaf temperatures were recorded in the field in $24 \mathrm{~h}$ cycles, while thermal analysis and injury temperature were determined in the laboratory. Both E. spicata and E. timotensis juveniles depend on avoidance mechanisms through a high supercooling capacity, permitting leaves to resist low nighttime temperatures. Minimum leaf temperatures were -4.9 and $-5.1^{\circ} \mathrm{C}$, for E. spicata and E. timotensis, respectively, occurring during the dry season. Ice formation occurred at -14.3 and $-15.3{ }^{\circ} \mathrm{C}$ for E. spicata and E. timotensis, respectively. Injury occurred at approximately $-15{ }^{\circ} \mathrm{C}$ in both species. Low temperature resistance mechanisms in juveniles are similar to those in adult plants.
\end{abstract}

(C) 2003 Éditions scientifiques et médicales Elsevier SAS. All rights reserved.

Keywords: Low temperature resistance; Supercooling capacity; Tropical high mountains; Venezuelan Andes; Espeletia spicata; Espeletia timotensis

\section{Introduction}

Low air temperatures and night frosts all year round characterize tropical high mountain ecosystems (Smith and Young, 1987). Hedberg (1964) describes this environment as "summer every day and winter every night" and these extreme daily oscillations in temperature constitute a critical stress factor for plants. Such conditions may limit growth and survival of plants in these habitats (Sakai and Larcher, 1987). Plants may contend with these conditions through freezing avoidance or freezing tolerance (Levitt, 1980). For example, adult plants of 14 Espeletia species, giant caulescent rosettes plants, dominant in the high Andean flora, possess freezing avoidance mechanisms (Goldstein et al., 1985; Rada et al., 1985).

Due to night reirradiation of the soil night temperatures are lower at ground level so plants that grow close to the ground suffer colder conditions. Azócar et al. (1988) found that the miniature rosette Draba chionophilla tolerates freezing, surviving ice formation in its leaf tissues. These authors

* Corresponding author.

E-mail address: frada@ ciens.ula.ve (F. Rada). suggest that plants growing close to the ground must tolerate freezing in order to survive these environments, while those growing away from the ground, i.e. trees and shrubs, rely on freezing avoidance mechanisms. Squeo et al. (1991, 1996) found such a relationship across a range of tropical and subtropical plants of different life forms along altitudinal gradients.

To clarify this relationship we compared juvenile with adult plants of two Espeletia species. The rosettes of adult plants are raised above the ground on a long trunk-like stalk to a height of $100 \mathrm{~cm}$ on average. Juveniles, on the other hand, grow at ground level and these experience lower night temperatures. We address the following questions: (1) through which mechanisms do plants of the upper strata (away from the ground) survive as juveniles, when they grow close to the ground? (2) Are juveniles freezing tolerant, changing to freezing avoidance strategies with increasing size? (3) If these plants use freezing avoidance mechanisms at all life stages, are these avoidance mechanisms more efficient while these plants are close to the ground compared to adult plants? 
Table 1

Injury temperature $(n=6)$, temperature at which freezing occurs (supercooling capacity, $n=6)$, absolute minimum leaf temperature $(n=4)$, minimum air temperature at $100 \mathrm{~cm}(n=3)$ and minimum ground level temperature $(n=3)$ measured for E. spicata and E. timotensis juvenile and adult a plants. Values are means \pm one standard error

\begin{tabular}{|c|c|c|c|c|c|c|}
\hline Species & Growth stage & $\begin{array}{l}\text { Injury temperature } \\
\left({ }^{\circ} \mathrm{C}\right)\end{array}$ & $\begin{array}{l}\text { Supercooling } \\
\text { capacity }\left({ }^{\circ} \mathrm{C}\right)\end{array}$ & $\begin{array}{l}\text { Minimum leaf } \\
\text { temperature }\left({ }^{\circ} \mathrm{C}\right)\end{array}$ & $\begin{array}{l}\text { Minimum air } \\
\text { temperature at } \\
100 \mathrm{~cm} \text { height }\left({ }^{\circ} \mathrm{C}\right)\end{array}$ & $\begin{array}{l}\text { Minimum } \\
\text { ground level } \\
\text { temperature }\left({ }^{\circ} \mathrm{C}\right)\end{array}$ \\
\hline \multirow[t]{2}{*}{ E. spicata } & Juvenile & $-15.2 \pm 1.4$ & $-14.3 \pm 0.5$ & $-4.9 \pm 0.5$ & $-1.8 \pm 0.3$ & $-2.7 \pm 0.2$ \\
\hline & Adult & $-13.0 \pm 0.9$ & $-13.6 \pm 0.7$ & $-2.0 \pm 0.3$ & & \\
\hline \multirow[t]{2}{*}{ E. timotensis } & Juvenile & $-15.3 \pm 0.8$ & $-15.3 \pm 1.7$ & $-5.1 \pm 0.4$ & $-2.2 \pm 0.4$ & $-3.4 \pm 0.3$ \\
\hline & Adult & $-13.5 \pm 1.1$ & $-12.9 \pm 0.6$ & $-1.0 \pm 0.5$ & & \\
\hline
\end{tabular}

${ }^{a}$ From Rada et al. (1985).

\section{Materials and methods}

The study was carried out on juveniles (between 5 and 10 $\mathrm{cm}$ in height) of Espeletia spicata Sch. Bip. Wedd. and Espeletia timotensis Cuatr. The site was located at the Páramo de Piedras Blancas in Venezuela at an altitude of $4200 \mathrm{~m}$, with a mean annual temperature of $2.8^{\circ} \mathrm{C}$ and 897 $\mathrm{mm}$ of precipitation, mostly falling between April and December (Monasterio, 1986). The minimum temperature registered near the soil at this site was $-9.0{ }^{\circ} \mathrm{C}$ (Pérez, 1984).

\subsection{Soil-air gradient and leaf temperature measurements}

Leaf temperature was measured on four individuals of each species chosen at random for six different $24-\mathrm{h}$ periods between March and July of 2000. At the same time temperature at ground level and $100 \mathrm{~cm}$ above ground level were measured. All temperature measurements ( $1 \mathrm{~h}$ intervals) were carried out with copper-constantan thermocouples.

\subsection{Injury temperature determinations}

Plants were taken to the laboratory and maintained in growth chambers simulating páramo temperature and light conditions. Injury temperature was determined by a TTC method used by Rada et al. (1985) on six individuals from each species. Leaf samples were placed in small hermetically sealed test tubes, placed in a refrigerated bath and temperature lowered from 5 to $-17.5^{\circ} \mathrm{C}$. At the initial temperature and at $5{ }^{\circ} \mathrm{C}$ intervals down to $-15{ }^{\circ} \mathrm{C}$, then at $-17.5{ }^{\circ} \mathrm{C}$, samples were taken out and incubated at $5{ }^{\circ} \mathrm{C}$ for $12 \mathrm{~h}$ after which the TTC solution was added. After a $24-\mathrm{h}$ period, the TTC solution was extracted with ethanol and the absorbance measured at $530 \mathrm{~nm}$. Frost injury temperature was considered as 50\% survival of tissues (Steponkus and Lanphear, 1967). Because frost injury can not occur at temperatures above $0{ }^{\circ} \mathrm{C}$, values inferior to $100 \%$ survival at these temperatures indicate some manipulation damage of the leaf sections.

\subsection{Thermal analysis}

Two leaves from each of six different individuals kept in a growth chamber were placed in small sealed test tubes and a copper-constantan thermocouple was installed. These samples were placed in a refrigerated bath and temperature was lowered from 5 to $-17.5{ }^{\circ} \mathrm{C}$. Temperatures were registered in a chart recorder. The appearance of an exotherm, due to the liberation of energy during freezing, indicated the temperature at which this process began and, therefore, the supercooling capacity was determined.

\section{Results}

Minimum leaf temperatures at night of juveniles of both species growing at ground level were significantly lower than those of adult plants Table 1 Rada et al., 1985). Freezing damage for leaves of both species occurred at -15.2 and $-15.3{ }^{\circ} \mathrm{C}$, respectively Table 1 Figs. 1 and 2) The temperatures at which ice formation began (i.e. supercooling capacity) for the two species were not significantly different from the injury temperatures Table 1 .

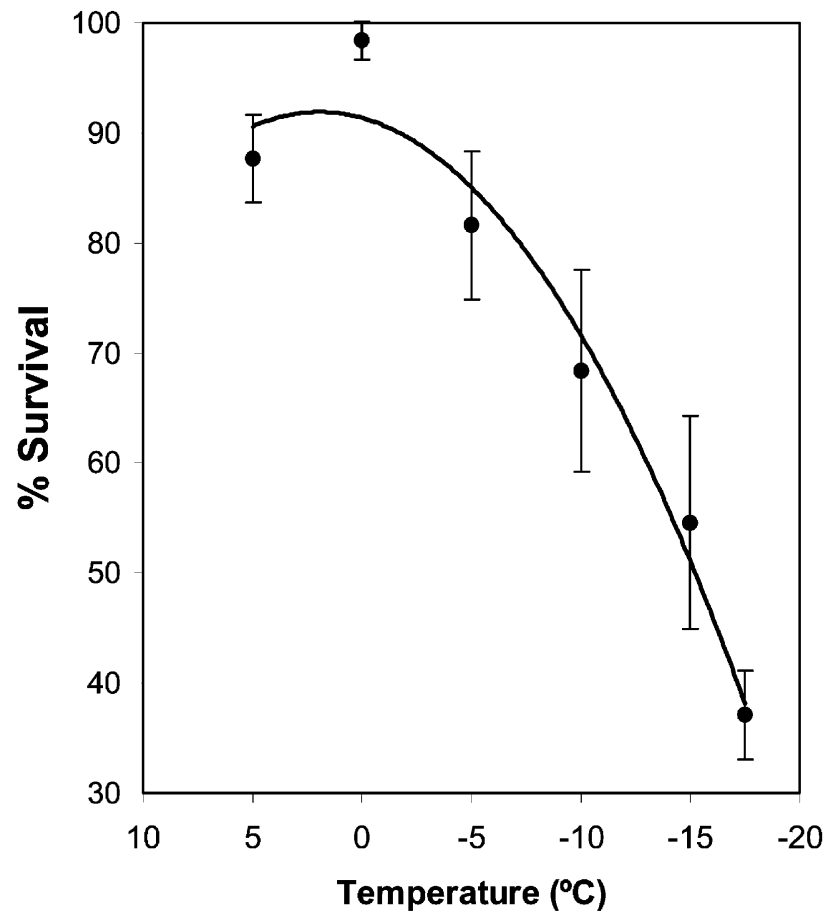

Fig. 1. Temperature-\%Survival relationship for E. spicata juveniles. Injury temperature is considered to correspond to $50 \%$. Bars indicate one standard error of the mean $\left(y=-0.14 x^{2}+0.55 x+91.37, r^{2}=0.96\right)$. 


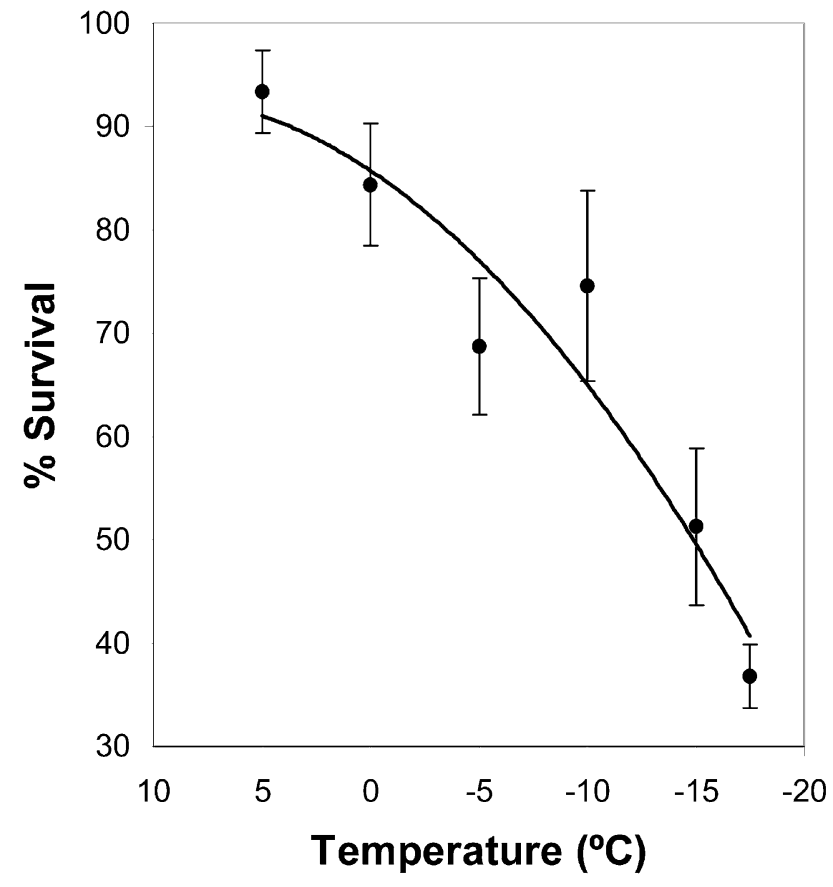

Fig. 2. Temperature-\%Survival relationship for E. timotensis juveniles. Injury temperature is considered to correspond to $50 \%$ injury. Bars indicate one standard error of the mean $\left(y=-0.07 x^{2}+1.40 x+85.75, r^{2}=0.92\right)$.

\section{Discussion}

The Venezuelan high mountain vegetation is dominated by giant caulescent rosette plants of the genus Espeletia. These plants persist in an environment with low temperatures and frequent night frosts all year round. Early stages of these plants must resist colder ground level conditions during several years before they can reach the warmer higher strata. Juvenile E. spicata and E. timotensis plants possess freezing avoidance mechanisms as do adult plants (Rada et al., 1985). Although the differences were not significant between life stages with our small sample sizes ice formation began at a lower temperature in juveniles than adults. An increase in supercooling capacity has been associated with cell properties such as small cell size, reduced or absent intercellular spaces, low relative water content and absence of ice nuclea- tors (Levitt, 1980; Sakai and Larcher, 1987). Rada et al. (1987) report an increase in supercooling capacity in Espeletia schultzii, along an altitudinal gradient, due to a decrease in mesophyll and epidermal cell size together with a reduction in size of intercellular spaces.

\section{Acknowledgements}

We thank David Dugarte for his assistance in the fieldwork. This study was supported by the CDCHT-ULA (grant No. C-963-99-01-F).

\section{References}

Azócar, A., Rada, F., Goldstein, G., 1988. Freezing tolerance in Draba chionophila, a 'miniature' caulescent rosette species. Oecologia 75, 156-160.

Goldstein, G., Rada, F., Azócar, A., 1985. Cold hardiness and supercooling along an altitudinal gradient in Andean rosette species. Oecologia 68, $147-152$.

Hedberg, O., 1964. Features of Afroalpine plant ecology. Acta Phytogeographic Suecica 49, 1-144.

Levitt, J., 1980. Responses of Plants to Environmental Stresses. Chilling, Freezing and High Temperature Stresses, vol. 1. Academic Press.

Monasterio, M., 1986. Adaptive strategies of Espeletia in the Andean Desert Paramo. In: Vuilleumier, F., Monasterio, M. (Eds.), High Altitude Tropical Biogeography. Oxford University Press,, Oxford, pp. 49-80.

Pérez, F.L., 1984. Striated soil in an Andean páramo of Venezuela: its origin and orientation. Arctic and Alpine Research 16, 277-289.

Rada, F., Goldstein, G., Azócar, A., Meinzer, F., 1985. Freezing avoidance in Andean giant rosette plants. Plant, Cell and Environment 8, 501-507.

Rada, F., Goldstein, G., Azócar, A., Torres, F., 1987. Supercooling along an altitudinal gradient in Espeletia schultzii, a caulescent giant rosette species. Journal of Experimental Botany 38, 491-497.

Sakai, A., Larcher, W., 1987. Frost survival of plants. Responses and Adaptation to Freezing Stress. Springer.

Smith, A., Young, T., 1987. Tropical alpine plant ecology. Annual Review of Ecology and Systematics 18, 137-158.

Squeo, F., Rada, F., Azócar, A., Goldstein, G., 1991. Freezing tolerance and avoidance in high tropical Andean plants: is it equally represented in species with different plant height? Oecologia 86, 378-382.

Squeo, F., Rada, F., García, C., Ponce, M., Rojas, A., Azócar, A., 1996. Cold resistance mechanisms in high Andean plants. Oecologia 105, 552-555.

Steponkus, P., Lanphear, F., 1967. Refinement of the triphenyl tetrazolium chloride method of determining cold injury. Plant Physiology 42, 14231426 . 